\title{
Effects of the conditioned medium of mesenchymal stem cells on mouse oocyte activation and development
}

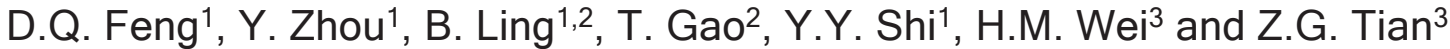

${ }^{1}$ Anhui Province Key Laboratory of Molecular Medicine, ${ }^{2}$ Department of Obstetrics and Gynecology, Anhui Provincial Hospital, Anhui Medical University, Hefei, China

${ }^{3}$ Institution of Immunology, Hefei National Laboratory for Physical Science at Microscale and School of Life Science, University of Science and Technology of China, Hefei, China

Correspondence to: B. Ling, Department of Obstetrics and Gynecology, Anhui Provincial Hospital Affiliated to Anhui Medical University, 17 Lu-Jiang Road, Hefei 230001, China

Fax: +86-551-228-2121. E-mail: lingbin.ling@gmail.com

\begin{abstract}
Mesenchymal stem cells (MSCs) have been reported to secrete a variety of cytokines and growth factors acting as trophic suppliers, but little is known regarding the effects of conditioned medium (CM) of MSCs isolated from femurs and tibias of mouse on the artificial activation of mouse oocytes and on the developmental competence of the parthenotes. In the current study, we investigated the effect of $\mathrm{CM}$ on the events of mouse oocyte activation, namely oscillations of cytosolic calcium concentration $\left(\left[\mathrm{Ca}^{2+}\right]_{i}\right)$, meiosis resumption, pronucleus formation, and parthenogenetic development. The surface markers of MSCs were identified with a fluorescence-activated cell sorter. The dynamic changes of the spindle and formation of pronuclei were examined by laser-scanning confocal microscopy. Exposure of cumulus-oocyte complexes to CM for 40 min was optimal for inducing oocyte parthenogenetic activation and evoking $\left[\mathrm{Ca}^{2+}\right]_{i}$ oscillations similar to those evoked by sperm (95 vs $100 \%$; P > 0.05). Parthenogenetically activated oocytes immediately treated with $7.5 \mu \mathrm{g} / \mathrm{mL}$ cytochalasin $B(C B)$, which inhibited spindle rotation and second polar body extrusion, were mostly diploid (93 vs $6 \%, \mathrm{P}<0.01$ ) while CB-untreated oocytes were mostly haploid ( 5 vs $83 \%, P<0.01$ ). Consequently, the blastocyst rate was higher in the $\mathrm{CB}$-treated than in the CB-untreated oocytes. There was no significant difference in developmental rate between oocytes activated with $\mathrm{CM}$ and $7 \%$ ethanol $(62$ vs $62 \%$, P > $0.05)$, but the developmental competence of the fertilized oocytes was superior to that of the parthenotes $(88 \mathrm{vs} 62 \%, \mathrm{P}<0.05)$. The present results demonstrate that $\mathrm{CM}$ can effectively activate mouse oocytes, as judged by the generation of $\left[\mathrm{Ca}^{2+}\right]_{\mathrm{i}}$ oscillations, completion of meiosis and parthenogenetic development.
\end{abstract}

Key words: Mesenchymal stem cells; Oocyte activation; Parthenogenesis; Calcium; Cytochalasin B

Research supported by grants from the China National Natural Science Foundation (\#34071805) and the Science Research Foundation, Anhui Provincial Hospital.

Received September 24, 2008. Accepted March 11, 2009

\section{Introduction}

Mesenchymal stem cells (MSCs), widely distributed in a variety of tissues in the adult organism, secrete many kinds of cytokines and growth factors, such as monocyte chemotactic protein-1, vascular endothelial growth factorA, epidermal growth factor (EGF), fibroblast growth factor2, interleukin-6, leukemia inhibitory factor, transforming growth factor- $\beta$, and so on $(1,2)$. We have demonstrated the trophic effects of these bioactive factors in supporting follicular growth and in vitro maturation of mouse oocytes (3). However, to our surprise, some MII oocytes cocultured with MSCs were activated, with the occurrence of cleavage, though none of these oocytes developed further in this culture. We later observed that the conditioned medium (CM) of MSCs, which undoubtedly contains many 
kinds of cytokines and growth factors resulting from the exocrinosity of MSCs, can act equally as a stimulant. Thus, we thought it would be useful to assess the ability of $\mathrm{CM}$ to activate mouse oocytes parthenogenetically, and embryo development before implantation.

Some of these secreted bioactive factors have been reported to improve meiotic maturation in vitro and subsequently the embryo developmental potential directly or via cumulus cells (4-6). Many studies have demonstrated a beneficial influence of leukemia inhibitory factor on embryo development in several species, such as improved cleavage of parthenogenetic embryos, higher rate of pronuclear-stage embryos with in vitro fertilization, a larger inner cell mass, and so on (7-9). The EGF receptor (EGFR) is present in cumulus cells and in oocyte at the germinal vesicle stage and following maturation. O'Donnell et al. (10) reported that activation of EGFR by EGF or transforming growth factor- $\alpha$ induces both auto- and trans-phosphorylation of EGFRs, which result in cytosolic calcium concentration $\left(\left[\mathrm{Ca}^{2+}\right]_{\mathrm{i}}\right)$ elevation and subsequent membrane permeabilization in mouse cumulus-oocyte complexes (COCs), but oocytes fail to respond to the EGF stimulus. However, to our knowledge, no information is available concerning the effect of CM on oocyte activation and on the development of preimplantation parthenogenotes.

A variety of artificial stimuli such as ethanol, electroporation, calcium ionophore, ionomycin, and inositol 1,4,5trisphosphate $\left(\operatorname{InsP}_{3}\right)$ are used to induce the parthenogenetic activation of mammalian oocytes (11-15). Yang et al. (13) reported that combined treatment with $7 \%$ ethanol for $10 \mathrm{~min}$ and cycloheximide, a protein synthesis inhibitor, improved the rate of activation of the young oocytes of cattle. The histone kinase inhibitor 6-dimethylaminopurine has been reported to accelerate and enhance the formation of pronuclei in non-aged MII oocytes from mice and cattle (16). Also, cytochalasin B (CB), an inhibitor of microfilament polymerization, prevents the release of the second polar body (Pb2) after oocyte activation, which would result in diploid development (17), and may also help prevent embryo fragmentation $(18,19)$.

These artificial stimuli mimicking sperm-triggered events evoke a series of $\left[\mathrm{Ca}^{2+}\right]_{i}$ oscillations, which is critical for oocyte activation. $\left[\mathrm{Ca}^{2+}\right]_{\mathrm{i}}$ oscillation triggers two important major events during activation: resumption of meiosis and pronuclear formation. Sperm-oocyte fusion initiates $\left[\mathrm{Ca}^{2+}\right]_{\mathrm{i}}$ oscillations that last several hours (20). Some activators, such as ionomycin or ethanol, cause a single $\left[\mathrm{Ca}^{2+}\right]_{\mathrm{i}}$ transient, while others such as $\operatorname{lns} \mathrm{P}_{3}$, adenophostin $\mathrm{A}$, thimerosal, and strontium evoke repetitive $\left[\mathrm{Ca}^{2+}\right]_{i}$ oscillations (21). Furthermore, some investigators have suggested that the type of $\left[\mathrm{Ca}^{2+}\right]_{\mathrm{i}}$ change is an important factor in promoting subsequent embryo development (22-24). Therefore, it is important to investigate $\left[\mathrm{Ca}^{2+}\right]_{\mathrm{i}}$ oscillations of oocytes treated with $\mathrm{CM}$ when judging the efficiency of $\mathrm{CM}$ for oocyte activation and embryo development.

In the present study, we investigated the pattern of $\left[\mathrm{Ca}^{2+}\right]_{i}$ changes in mouse oocytes after treatment with $\mathrm{CM}$, and the effects of time of exposure to $\mathrm{CM}$ and to a sequential combination of $\mathrm{CM}$ and $\mathrm{CB}$ in improving parthenogenetic activation and development of mouse oocytes.

\section{Material and Methods}

\section{Care and use of animals}

Kunming mice, originally derived from ICR (CD1) animals, were housed in a controlled environment $\left(20-25^{\circ} \mathrm{C}\right.$, $40-60 \%$ humidity, and a 8:00-20:00-light cycle). Female mice of the F1 strain, 6-8 weeks old, were used. Animal care and handling were in accordance with the policies issued by the Ethics Committee of Anhui Provincial Hospital affiliated to Anhui Medical University.

\section{Isolation of mesenchymal stem cells and preparation of} conditioned medium

Mice were deeply anesthetized with chloral hydrate and decapitated. Bone marrow was collected by flushing femurs and tibias with DMEM-HG (Gibco ${ }^{\mathrm{TM}}$, Invitrogen Corporation, USA). Mononuclear cells were harvested by separation with $60 \%$ Percoll (Amersham Biosciences, USA) separation (density: $1.077 \mathrm{~g} / \mathrm{mL}, 800 \mathrm{~g}$ for $20 \mathrm{~min}$ ) and washed twice (270 $\mathrm{g}$ for $10 \mathrm{~min}$ ) in DMEM-HG. Cells were then incubated in complete medium consisting of DMEM$\mathrm{HG}, 10 \%$ fetal calf serum (Gibco ${ }^{\mathrm{TM}}$, Invitrogen Corporation), $100 \mathrm{U} / \mathrm{mL}$ penicillin and $100 \mathrm{mg} / \mathrm{mL}$, at a density of 5 $x 10^{6}$ cells $/ \mathrm{mL}$. After 3 days, nonadherent cells were removed by two to three washes with 1 X PBS and adherent cells were further cultured in complete medium to $90 \%$ confluence. At this time, adherent cells were trypsinized and seeded at a density of $3 \times 10^{5}$ cells $/ \mathrm{mL}$ for further expansion. After $48 \mathrm{~h}$, the supernatant was collected as $\mathrm{CM}$ and filtered through a $0.2-\mu \mathrm{m}$ filter for immediate use. Surface markers of MSCs, CD11b, CD34, CD44, and CD105, were analyzed with a fluorescence-activated cell sorter (FACS). FITC-anti-CD11b, FITC-anti-CD34, PE-cy5anti-CD44, and PE-anti-CD105 were purchased from eBioscience (USA).

\section{Superovulation and collection of mouse oocytes}

Female mice were induced to superovulate by injection of pregnant mare's serum gonadotropin (PMSG) (7.5 IU, ip, Hangzhou Animal Medicine Factory, China), followed $48 \mathrm{~h}$ later by injection of human chorionic gonadotropin 
(hCG) (7.5 IU, ip, Hangzhou Animal Medicine Factory). The superovulated mice were killed $14 \mathrm{~h}$ after hCG injection, and the COCs were released from the oviductal ampullae into pre-equilibrated M16 medium (Sigma, USA). The COCs and denuded MII oocytes, which were freed of cumulus cells by a brief exposure to $0.1 \%(\mathrm{w} / \mathrm{v})$ hyaluronidase (Sigma), were used for in vitro activation. All manipulations were performed on a thermostatic plate $\left(37^{\circ} \mathrm{C}\right)$.

\section{Parthenogenetic activation}

COCs and denuded MII oocytes were treated with freshly prepared CM for $0,10,40 \mathrm{~min}, 1$, or $2 \mathrm{~h}$. Cumulus cells in COCs were dispersed with hyaluronidase after CM treatment. Also, oocytes were activated with CZB medium containing $7 \%$ ethanol for $6 \mathrm{~min}$. After activation, the oocytes were washed three times with M16 and further cultured in CZB medium containing $0.4 \%$ BSA (Sigma) in a 4-well Petri dish (Nunc, Denmark). Other batches of COC used as control were incubated with DMEM-HG containing $10 \%$ fetal calf serum for $0,10,40 \mathrm{~min}, 1$, or $2 \mathrm{~h}$ followed by additional incubation in CZB medium containing $0.4 \%$ BSA after cumulus cells were removed by hyaluronidase. Oocytes that exited MII arrest and resumed meiosis were considered to have been activated. At $48 \mathrm{~h}$ post-activation, glutamine and glucose were directly injected into one drop of CZB to give a final concentration of 1 and $5.56 \mathrm{mM}$, respectively, which supported embryo development to the morula and blastocyst stages (25).

\section{Treatment with $\mathrm{CB}$}

Cytochalasin B (Sigma) was dissolved as a stock solution $(1 \mathrm{mg} / \mathrm{mL}$ ) in dimethylsulfoxide (Sigma) and stored at $-20^{\circ} \mathrm{C}$. It was later diluted to a final concentration of $7.5 \mu \mathrm{g} /$ $\mathrm{mL}$ in CZB containing $0.4 \%$ BSA. The parthenogenetically activated oocytes were sequentially treated with $\mathrm{CB}$ for 4 $\mathrm{h}$. The oocytes were removed from the medium containing $\mathrm{CB}$, washed at least three times with $\mathrm{M} 16$, and then cultured in CB-free CZB containing $0.4 \%$ BSA. At $48 \mathrm{~h}$, glutamine and glucose were directly injected into the culture medium of CZB to a final concentration of 1 and 5.56 $\mathrm{mM}$, respectively.

\section{In vivo/in vitro fertilization}

The PMSG- and hCG-primed female mice were allowed to mate overnight with males of proven fertility. In vivo fertilized oocytes were isolated into M16 medium from the oviductal ampullae of mice $15 \mathrm{~h}$ after hCG administration. Cumulus cells were removed as described earlier for MII oocytes and then cultured in CZB containing $0.4 \%$ BSA. Glutamine and glucose at final concentrations of 1 and $5.56 \mathrm{mM}$, respectively, were added to the culture drop at $48 \mathrm{~h}$

For in vitro fertilization, MII oocytes were treated with $0.5 \%(\mathrm{w} / \mathrm{v})$ protease $\mathrm{E}$ (BioShare, Germany) to remove the zona pellucida (ZP) prior to insemination. Sperm were collected from the cauda epididymis of the males, capacitated for 1-1.5 h, and diluted in HTF Xtra medium (LifeGlobal, USA) to a final concentration of 0.7-1.3 $\times 10^{6} \mathrm{sperm} / \mathrm{mL}$. Insemination of ZP-free oocytes by capacitated sperm was performed in a thermostatic 4-well Petri dish, suitable for $\left[\mathrm{Ca}^{2+}\right]_{\mathrm{i}}$ measurements, as previously described (26).

\section{Measurement of $\left[\mathrm{Ca}^{2+}\right]_{i}$}

To monitor $\left[\mathrm{Ca}^{2+}\right]_{\mathrm{i}}$ changes, COCs and denuded oocytes, either ZP-enclosed or ZP-free, were loaded with the $\mathrm{Ca}^{2+}$-sensitive dye, fura-2-AM ( $3 \mu \mathrm{M}$; Sigma), for $30 \mathrm{~min}$ in $\mathrm{Ca}^{2+} / \mathrm{Mg}^{2+}$-free $\mathrm{M} 2$ medium at $37^{\circ} \mathrm{C}$. After dye loading, COCs and denuded oocytes were washed free of the dye and transferred to a polylysine-coated coverslip mounted on a 4-well Petri dish held at $37^{\circ} \mathrm{C}$. COCs and denuded oocytes were stimulated by the addition of reagents directly to the cell dish. Free $\left[\mathrm{Ca}^{2+}\right]_{i}$ was determined by monitoring the fluorescence ratio at $340 / 380 \mathrm{~nm}$ excitation wavelengths using an inverted microscope (Zeiss, Axiovert, Germany) after appropriate background fluorescence subtraction. In all cases, data were sampled at 5-s intervals.

\section{Immunofluorescent staining and confocal microscopy}

At various times after activation $(0,1,2,4,6,12,16,20$, $24 \mathrm{~h}$ ), oocytes were fixed with $3.7 \%$ (w/v) paraformaldehyde in PBS containing $0.1 \%$ (v/v) Triton X-100 for $30 \mathrm{~min}$ at $37^{\circ} \mathrm{C}$. Fixed oocytes were stored until processing at $4^{\circ} \mathrm{C}$ in a PBS blocking solution containing $1 \%(\mathrm{w} / \mathrm{v}) \mathrm{BSA}, 2 \%$ (v/ v) normal goat serum, $0.1 \mathrm{~mol}$ glycine, $0.2 \%(\mathrm{w} / \mathrm{v})$ sodium azide, and $0.01 \%(\mathrm{v} / \mathrm{v})$ Triton X-100. A double-labeling protocol was used for the detection of microtubules and chromatin by confocal microscopy. Oocytes were first incubated for $1 \mathrm{~h}$ at $37^{\circ} \mathrm{C}$ in a mixture of mouse monoclonal anti $\alpha$-tubulin and $\beta$-tubulin (Sigma) antibodies at a 1:500 final dilution in PBS blocking solution. After two washes in $0.1 \%(\mathrm{w} / \mathrm{v})$ polyvinylpyrrolidone (PVP)/PBS at room temperature, oocytes were incubated at $37^{\circ} \mathrm{C}$ in PBS blocking solution alone for $30 \mathrm{~min}$, and then in a 1:100 dilution of goat anti-mouse fluorescein-conjugated IgG (Santa Cruz, USA) for $45 \mathrm{~min}$ at $37^{\circ} \mathrm{C}$. Oocytes were washed again twice in $0.1 \%$ PVP/PBS, and incubated at room temperature for $10 \mathrm{~min}$ in $10 \mu \mathrm{g} / \mathrm{mL}$ propidium iodide (Sigma) and mounted in $70 \%(\mathrm{v} / \mathrm{v})$ glycerol/PBS containing $25 \mathrm{mg} / \mathrm{mL}$ sodium azide. Controls included nonimmune and secondary antibody alone, which did not detect spindles, microtubules or midbodies. The samples were examined with a laser-scanning confocal microscopy (Zeiss, LSM510). 


\section{Statistical analysis}

Data are reported as the means \pm SEM of three replicates of each experiment. Differences between treatment groups were determined by the chi-square test, with the level of significance set at $\mathrm{P}<0.05$.

\section{Results}

Characterization of mesenchymal stem cells

MSCs of passage two showed typical fibroblast morphology with large flat and spindle-shaped cells, as did primary MSCs. FACS analysis demonstrated that these cells were negative for CD34 and CD11b, and positive for CD44 and CD105, consistent with the general agreement that MSCs lack typical hematopoietic antigens and markers of granulo-monocytic cells, namely, CD34 and CD11b (27).

The effect of $\mathrm{CM}$ on $\left[\mathrm{Ca}^{2+}\right]_{i}$ changes

A very early observable event occurring after spermoocyte interaction or after parthenogenetic activation is an increase in $\left[\mathrm{Ca}^{2+}\right]_{i}$. Oocytes in COCs treated with $\mathrm{CM}$ exhibited an initial $\left[\mathrm{Ca}^{2+}\right]_{\mathrm{i}}$ transient at $12-30 \mathrm{~min}$, that was followed by a series of irregular $\left[\mathrm{Ca}^{2+}\right]_{i}$ oscillations of lower amplitude $(0.41 \pm 0.05$ arbitrary units) and longer peak-topeak intervals $(7.11 \pm 1.59 \mathrm{~min}$; Figure $1 \mathrm{C})$, whereas the oscillations in fertilized oocytes were regular, with greater amplitude $(0.83 \pm 0.13$ arbitrary units) and shorter intervals $\left(3.15 \pm 0.37 \mathrm{~min} ;\right.$ Figure 1A). In general, $\left[\mathrm{Ca}^{2+}\right]_{\mathrm{i}}$ increased slowly in CM-treated oocytes and all sequential changes occurred above the basal level. Oocytes treated with 7\% ethanol presented a single rise in $\left[\mathrm{Ca}^{2+}\right]_{\mathrm{i}}$, which increased rapidly from the basal level to the peak level, and then slowly decreased but did not return to the basal level within 6 min (Figure 1B).

Effects of $\mathrm{CM}$ on the activation of mouse oocytes in the presence or not of $\mathrm{CB}$

Significantly more oocytes (approximately 95\%) were activated at the CM exposure times of $40 \mathrm{~min}, 1$ and $2 \mathrm{~h}$ than at shorter exposure times as shown in Table 1. There was no difference between exposure for $40 \mathrm{~min}, 1$ and $2 \mathrm{~h}$, but the oocytes treated for 40 min developed well, while embryo fragmentation increased with exposure time. The optimal time for denuded MII oocyte activation (approximately $95 \%$ ) was not 40 min but $2 \mathrm{~h}$ (data not shown).

To study the effect of CB on the development of activated oocytes, COCs were treated with $\mathrm{CM}$ for $40 \mathrm{~min}$, followed by culture for $4 \mathrm{~h}$ in CZB with or without $7.5 \mu \mathrm{g} / \mathrm{mL}$ $\mathrm{CB}$ after cumulus cells were removed. No significant difference in activation rate was observed in the presence or absence of CB (Table 2). However, most of the oocytes treated with $\mathrm{CB}$ had two pronuclei, whereas most of the activated oocytes without $\mathrm{CB}$ treatment contained one pronucleus or cleaved immediately. Since CB inhibited the second polar body extrusion, the activated oocytes treated
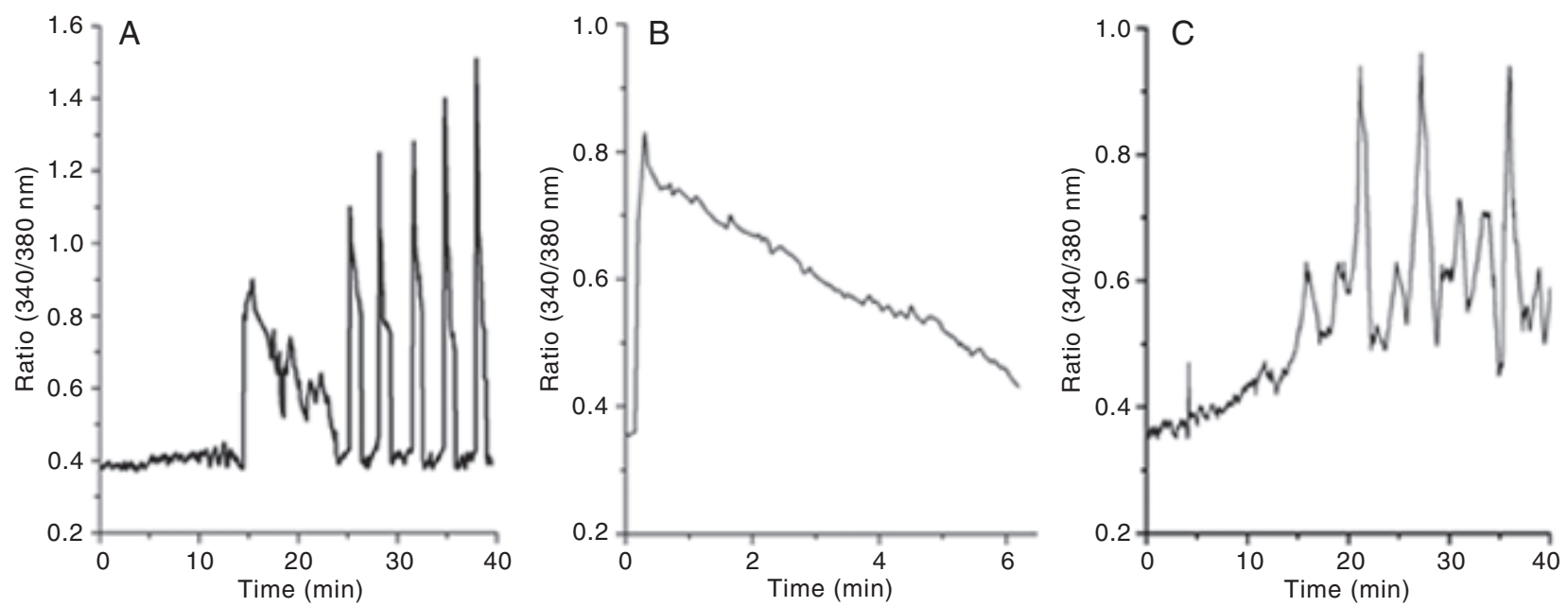

Figure 1. Fertilization-, ethanol-, and conditioned medium (CM)-induced $\left[\mathrm{Ca}^{2+}\right]_{i}$ changes in fura-2-AM-loaded mouse oocytes. $A$, During in vitro fertilization, sperm triggered an initial $\left[\mathrm{Ca}^{2+}\right]_{\mathrm{i}}$ transient that was followed by a series of regular and high $\left[\mathrm{Ca}^{2+}\right]_{\mathrm{i}}$ oscillations. $B, A$ single rapid $\left[\mathrm{Ca}^{2+}\right]_{i}$ rise was observed in $7 \%$ ethanol-treated oocytes, which decreased slowly. C) The type of $\left[\mathrm{Ca}^{2+}\right]_{i}$ changes in $\mathrm{CM}$-treated oocytes was similar to that induced by sperm. The amplitude of the initial $\left[\mathrm{Ca}^{2+}\right]_{\mathrm{i}}$ transient was lower than the subsequent $\left[\mathrm{Ca}^{2+}\right]_{i}$ oscillations, whereas the oscillations induced by $\mathrm{CM}$ were of lower amplitude and longer duration than those induced by sperm. 
with $C B$ mostly formed diploid zygotes while those not treated with $\mathrm{CB}$ mostly formed haploid zygotes. A significantly higher proportion of activated oocytes in the group treated with $\mathrm{CB}$ developed into blastocysts than in the group not treated with CB (Table 2).

\section{Dynamic changes of the spindle following parthenogenetic activation}

Microtubules were found mainly in the well-organized spindle in MII oocytes by immunofluorescent staining. The spindle was symmetrical, bipolar, barrel-shaped, and located near the cortex of the oocyte. From 1 to $3 \mathrm{~h}$ postactivation, as the oocyte exited MII and progressed to anaphase II and subsequently to telophase II, the sister chromatids migrated to opposite poles of the spindle, followed spindle rotation from parallel to vertical in relation to the surface of the oocyte (Figure 2A). The spindle then elongated and formed $\mathrm{Pb} 2$, which was extruded into the perivitelline space.

Neither the resumption of meiosis nor the separation of daughter chromatids was disturbed after oocyte activation with $\mathrm{CM}$ followed by treatment with $7.5 \mu \mathrm{g} / \mathrm{mL}$ CB for $4 \mathrm{~h}$. However, in CB-treated parthenogenetically activated oocytes, spindle rotation and $\mathrm{Pb} 2$

Figure 2. Resumption of meiosis induced by conditioned medium (CM) and effects of cytochalasin $\mathrm{B}(\mathrm{CB})$ on spindle rotation and pronucleus formation. Microtubules (green) and chromatin (red) were stained with anti-tubulin antibodies and propidium iodide, respectively. After 40-min exposure to $\mathrm{CM}$, MII arrested oocytes in cumulus-oocyte complexes (COCs) resumed meiosis. A, At 1-3 h post-activation in the absence of $\mathrm{CB}$, the first polar body $(\mathrm{Pb} 1)$ extruded into the perivitelline space while the telophase spindle showed an orientation perpendicular to the plasma membrane, and daughter chromosomes separated towards the two spindle poles (SP). B, At 1 to $4 \mathrm{~h}$ of CB treatment, the oocytes failed to undergo spindle rotation. $C$ and $D$, At 0 to $2 \mathrm{~h}$ post-CB treatment, because the second polar body (Pb2) extrusion was inhibited, two pronuclei (PN) containing multiple nucleoli formed in the cytoplasm connected with a midbody (MB). Scale bar $=20 \mu \mathrm{m}$ for all panels.
Table 1. Effect of mesenchymal stem cell conditioned medium (CM) on the activation of mouse oocytes.

\begin{tabular}{lcc}
\hline $\begin{array}{l}\text { Duration of } \\
\text { CM treatment }\end{array}$ & $\begin{array}{c}\text { No. of oocytes } \\
\text { examined }\end{array}$ & $\begin{array}{c}\text { Activated } \\
\text { oocytes (\%) }\end{array}$ \\
\hline 0 min & 59 & $6 \pm 3 \%^{\mathrm{a}}$ \\
$10 \mathrm{~min}$ & 106 & $46 \pm 10 \% \mathrm{~b}$ \\
$40 \mathrm{~min}$ & 104 & $95 \pm 2 \%^{\mathrm{c}}$ \\
$1 \mathrm{~h}$ & 97 & $95 \pm 2 \%^{\mathrm{c}}$ \\
$2 \mathrm{~h}$ & 102 & $96 \pm 2 \% \mathrm{c}$ \\
\hline
\end{tabular}

Data are reported as means \pm SD for activated oocytes. Values with different superscript letters differed significantly $(P<0.01$, chi-square test).

Table 2. Effect of cytochalasin B (CB) treatment on the activation and development of mouse oocytes.

\begin{tabular}{|c|c|c|c|c|c|c|}
\hline \multirow{2}{*}{ CB } & \multirow{2}{*}{$\begin{array}{c}\text { No. of } \\
\text { oocytes }\end{array}$} & \multirow{2}{*}{$\begin{array}{c}\text { Activated } \\
\text { oocytes (\%) }\end{array}$} & \multicolumn{3}{|c|}{ Activated oocytes (\%) with } & \multirow{2}{*}{$\begin{array}{c}\text { Blastocyst } \\
(\%)\end{array}$} \\
\hline & & & 1 pronucleus & 2 pronuclei & $\begin{array}{l}\text { Fragmented } \\
\text { cytoplasm }\end{array}$ & \\
\hline+ & 109 & $97 \pm 2 \%$ & $5 \pm 1^{*}$ & $93 \pm 3^{*}$ & $0^{*}$ & $59 \pm 2^{*}$ \\
\hline- & 94 & $95 \pm 2 \%$ & $83 \pm 2$ & $6 \pm 2$ & $7 \pm 3$ & $10 \pm 3$ \\
\hline
\end{tabular}

Data are reported as means $\pm S D$. ${ }^{*} P<0.01$ compared to oocytes not treated with CB (chi-square test).
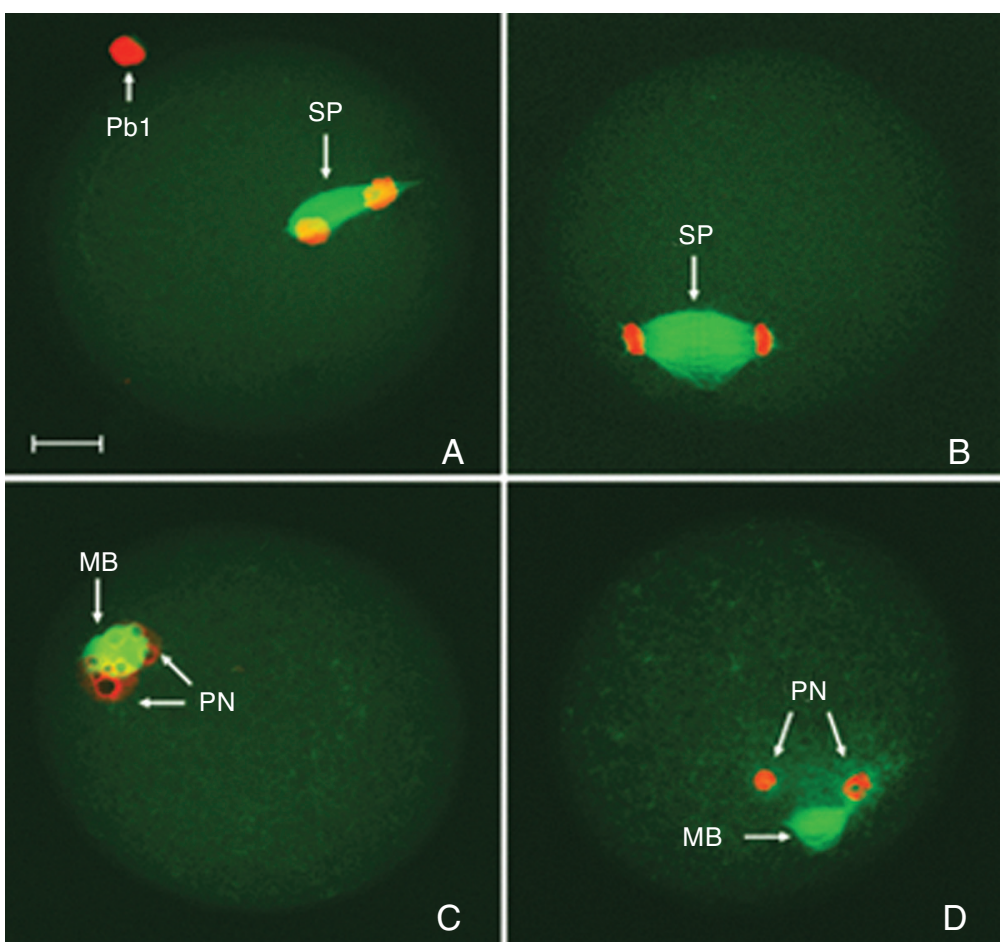
extrusion were inhibited. At 1 to $4 \mathrm{~h}$ of $\mathrm{CB}$ treatment, spindles were still parallel to the surface of the oocytes (Figure 2B). As no Pb2 extruded, these treated oocytes were diploid, containing two haploid female pronuclei connected at the midbody in the cytoplasm at $0-2 \mathrm{~h}$ after $4 \mathrm{~h}$ of CB treatment (Figure 2C,D).

\section{Development of activated oocytes}

At 4-6 $\mathrm{h}$ post-CM treatment, the activated oocytes completed the second meiosis and entered mitosis (Figure $3 A-F)$. The activated oocytes without CB treatment developed faster than those with $4 \mathrm{~h}$ of $\mathrm{CB}$ treatment, a fact that may have been partly due to immediate cleavage of the parthenotes or cytokinesis post-activation in the absence of CB. At $24 \mathrm{~h}$ post-activation, approximately $62 \%$ of the oocytes without $\mathrm{CB}$ treatment developed to the 3- to 8-cell stage, which in a small proportion of cases exhibited abnormal morphology with many cleavage furrows and many nuclei within an intact membrane (Figure 3D,F), while CB-treated oocytes were mostly (80\%) at the 2-cell stage with normal morphology, i.e., with two nuclei containing several nucleoli (Figure 3C,E). Moreover, the $\mathrm{CM}$ activated oocytes with or without the presence of $\mathrm{CB}$ developed faster than the oocytes activated with $7 \%$ ethanol or by fertilization, and the rate of blastocyst formation did not differ between the group treated with $\mathrm{CM}$ in combination with $\mathrm{CB}$ and the group treated with $7 \%$ ethanol but was significantly lower in both compared to the fertilized group at $96 \mathrm{~h}$ post-activation (Table 3).

\section{Discussion}

In the present study, experiments were undertaken to investigate the effects of $\mathrm{CM}$ on mouse oocyte activation, the pattern of $\left[\mathrm{Ca}^{2+}\right]_{i}$ changes, and the kinetics of key nuclear events of activated oocytes, such as meiotic cell cycle resumption, spindle rotation, $\mathrm{Pb} 2$ extrusion, and pronucleus formation. Oocytes collected from the F1 strain
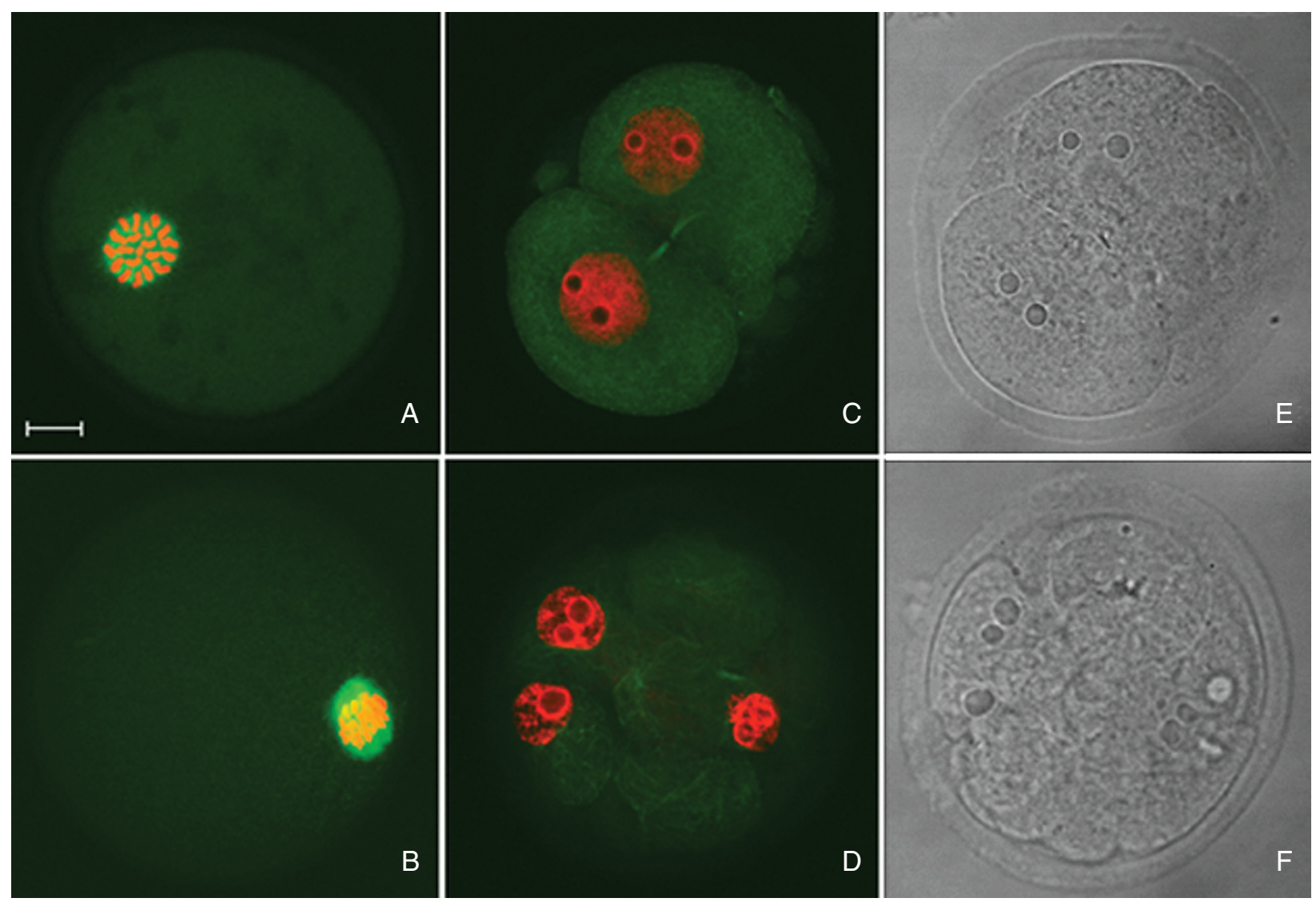

Figure 3. Development of the parthenogenetic embryos. Microtubules (green) and chromatin (red) were stained with anti-tubulin antibodies and propidium iodide, respectively. At 4 to $6 \mathrm{~h}$, the activated oocytes entered mitosis. A, Oocyte at prometaphase. $B$, Oocyte at mitosis metaphase. $C$ and $E$, At $24 \mathrm{~h}$, activated oocytes formed a 2-cell embryo after $4 \mathrm{~h}$ of cytochalasin $\mathrm{B}$ treatment. $D$ and $F$, At $24 \mathrm{~h}$, activated oocytes without cytochalasin B treatment formed a 3-cell embryo with cytokinesis. Bar $=20 \mu \mathrm{m}$ for all panels. 
Table 3. Development of activated mouse oocytes cultured in vitro in CZB medium.

\begin{tabular}{|c|c|c|c|c|c|c|}
\hline \multirow[t]{2}{*}{ Treatment } & \multirow{2}{*}{$\begin{array}{c}\text { No. of } \\
\text { oocytes }\end{array}$} & \multicolumn{3}{|c|}{ At $24 \mathrm{~h}$} & \multicolumn{2}{|c|}{ At $96 \mathrm{~h}$} \\
\hline & & $\begin{array}{c}\text { 1-cell } \\
\text { embryos } \\
(\%)\end{array}$ & $\begin{array}{c}\text { 2-cell } \\
\text { embryos } \\
(\%)\end{array}$ & $\begin{array}{c}\text { 3-8 cell } \\
\text { embryos } \\
(\%)\end{array}$ & $\begin{array}{c}\text { Morulae } \\
(\%)\end{array}$ & $\begin{array}{c}\text { Blastocysts } \\
(\%)\end{array}$ \\
\hline $\mathrm{CM}$ & 114 & $0 \%$ & $26 \pm 9 \%$ & $62 \pm 12 \%$ & $56 \pm 7 \%$ & $9 \pm 3 \%$ \\
\hline $\mathrm{CM}+\mathrm{CB}$ & 119 & $8 \pm 4 \%$ * & $80 \pm 6 \% *$ & $9 \pm 4 \%$ * & $15 \pm 3 \%$ * & $62 \pm 2 \%$ * \\
\hline $7 \%$ ethanol $+C B$ & 107 & $96 \pm 1 \%$ & $3 \pm 1 \%$ & $0 \%$ & $9 \pm 2 \%$ & $62 \pm 3 \% *$ \\
\hline Fertilized control & 68 & $0 \%$ & $100 \%$ & $0 \%$ & $0 \%$ & $88 \pm 8 \%$ \\
\hline
\end{tabular}

Data are reported as means $\pm \mathrm{SD}$. $\mathrm{CM}=$ conditioned medium of mesenchymal stem cells; $\mathrm{CB}=$ cytochalasin B. ${ }^{*} P<0.05$ compared with other treatments (chi-square test).

of Kunming mice were treated with $\mathrm{CM}$ for 0,10 and 40 min and for 1 and $2 \mathrm{~h}$. As shown here, mouse oocytes can be effectively activated by $\mathrm{CM}$ treatment. The optimal time was 40 min for COCs but $2 \mathrm{~h}$ for denuded oocytes. Second polar body extrusion and fragmented cytoplasm increased as $\mathrm{CM}$ exposure exceeded the optimum time. A small fraction $(6 \%)$ of mouse MII oocytes cultured in DMEM-HG or CZB without any known parthenogenetic stimulants initiated parthenogenetic activation spontaneously, which is a common phenomenon in lower vertebrate species and amphibians (28).

$\left[\mathrm{Ca}^{2+}\right]_{i}$ elevation is the early observable sign of oocyte activation, and triggers meiosis resumption and pronuclear formation. Recent studies have demonstrated that $\left[\mathrm{Ca}^{2+}\right]_{\mathrm{i}}$ mediates the degradation of cyclin $\mathrm{B} 1$ by increasing the activity of an E3 ubiquitin ligase $(29,30)$. Cyclin B1 is the regulatory subunit of $\mathrm{M}$-phase promoting factor and its destruction is required for meiosis resumption $(31,32)$. In the present study, CM, as well as sperm and ethanol induced $\left[\mathrm{Ca}^{2+}\right]_{\mathrm{i}}$ elevation. All of these activators caused mouse oocyte activation but induced different patterns of $\left[\mathrm{Ca}^{2+}\right]_{\mathrm{i}}$ changes. CM induced a smaller first calcium transient, followed by oscillations that were lower in amplitude, more prolonged and of lower frequency than those induced by sperm. By comparison, ethanol induced only a single calcium transient. The first $\left[\mathrm{Ca}^{2+}\right]_{i}$ transient occurred at 12-30 min in CM-treated oocytes, so 10 min of exposure time was not enough to activate oocyte effectively. Exposure to CM for 40 min induced 3-4 $\left[\mathrm{Ca}^{2+}\right]_{i}$ oscillations, was optimal for oocyte activation, and exhibited a better development than 1- and 2-h treatment, possibly reflecting the toxic effects of prolonged $\left[\mathrm{Ca}^{2+}\right]_{i}$ oscillations. In this experiment, the oocyte in COCs can be activated with CM more easily than the denuded oocyte, an event that may have been partly due to the $\mathrm{Ca}^{2+}$ transients generated in the cumulus cells and/or other messengers diffused to the oocyte via gap junctions, with a resulting increase in $\mathrm{Ca}^{2+}$ in the oocyte $(33,34)$.

Cytochalasin B, a microfilament-depolymerizing drug widely used in animal cloning $(35,36)$ and parthenogenetic activation $(14,15)$, can inhibit polar body extrusion and therefore chromosome expulsion; in the presence of cytochalasin B, chromosome segregation occurred, but spindle rotation and cytokinesis did not take place. This resulted in diploid zygotes with two pronuclei $(14,15,17$, $35,37)$. The present results show that CB did not affect chromosomal movement or nuclear division but did inhibit spindle rotation and, thus, cytokinesis. Ninety-three percent of CM-activated oocytes combined with $4 \mathrm{~h}$ of $\mathrm{CB}$ treatment formed diploid zygotes containing two pronuclei while $83 \%$ of activated oocytes without CB treatment extruded the second polar bodies and formed haploid zygotes. Some of them even cleaved immediately, though activation rates were similar irrespective of the presence or absence of CB. The embryos developed faster in the absence than in the presence of $C B$, but the rate of blastocyst was lower in the absence of $\mathrm{CB}$, and the embryos with abnormal morphology, such as fragmented cytoplasm, cytokinesis, were frequently observed in this group. As far as the parthenogenetic development is concerned, it was obvious that the beneficial effect of CB treatment post-oocyte activation was due to the diploidization of parthenotes. It is well known that diploid parthenotes are less apoptotic and have greater developmental capacity than haploid parthenotes $(38,39)$.

The results of the present study demonstrate that $\mathrm{CM}$ can act as an effective parthenogenetic agent, fairly mimicking the important events of oocyte activation, namely, $\left[\mathrm{Ca}^{2+}\right]_{i}$ elevation, meiosis resumption, pronuclear formation, and parthenogenetic development. However, the efficient component that induced activation in $\mathrm{CM}$ is less clear and merits further study. 


\section{Acknowledgments}

We thank Dr. Hai L. Hou (Louisiana State University Health Sciences Center, New Orleans) for helpful com- ments and a critical reading of the manuscript. We also thank Mr. Xu Wu (School of Life Science, University of Science and Technology of China, Hefei City) for assistance with the confocal microscopy experiments.

\section{References}

1. Caplan Al, Dennis JE. Mesenchymal stem cells as trophic mediators. J Cell Biochem 2006; 98: 1076-1084.

2. Heil M, Ziegelhoeffer T, Mees B, Schaper W. A different outlook on the role of bone marrow stem cells in vascular growth: bone marrow delivers software not hardware. Circ Res 2004; 94: 573-574.

3. Ling B, Feng DQ, Zhou Y, Gao T, Wei HM, Tian ZG. Effect of conditioned medium of mesenchymal stem cells on the in vitro maturation and subsequent development of mouse oocyte. Braz J Med Biol Res 2008; 41: 978-985.

4. Sutton ML, Gilchrist RB, Thompson JG. Effects of in-vivo and in-vitro environments on the metabolism of the cumulus-oocyte complex and its influence on oocyte developmental capacity. Hum Reprod Update 2003; 9: 35-48.

5. Chian RC, Buckett WM, Tan SL. In-vitro maturation of human oocytes. Reprod Biomed Online 2004; 8: 148-166.

6. Martins da Silva SJ, Gardner JO, Taylor JE, Springbett A, De Sousa PA, Anderson RA. Brain-derived neurotrophic factor promotes bovine oocyte cytoplasmic competence for embryo development. Reproduction 2005; 129: 423-434.

7. Tsai HD, Chang CC, Hsieh YY, Lo HY, Hsu LW, Chang SC. Recombinant human leukemia inhibitory factor enhances the development of preimplantation mouse embryo in vitro. Fertil Steril 1999; 71: 722-725.

8. Dunglison GF, Barlow DH, Sargent IL. Leukaemia inhibitory factor significantly enhances the blastocyst formation rates of human embryos cultured in serum-free medium. Hum Reprod 1996; 11: 191-196.

9. Ptak G, Lopes F, Matsukawa K, Tischner M, Loi P. Leukaemia inhibitory factor enhances sheep fertilization in vitro via an influence on the oocyte. Theriogenology 2006; 65: 1891-1899.

10. O'Donnell JB Jr, Hill JL, Gross DJ. Epidermal growth factor activates cytosolic $\left[\mathrm{Ca}^{2+}\right.$ ] elevations and subsequent membrane permeabilization in mouse cumulus-oocyte complexes. Reproduction 2004; 127: 207-220.

11. Fissore RA, Robl JM. Intracellular $\mathrm{Ca}^{2+}$ response of rabbit oocytes to electrical stimulation. Mol Reprod Dev 1992; 32: 9-16.

12. Mitalipov SM, White KL, Farrar VR, Morrey J, Reed WA. Development of nuclear transfer and parthenogenetic rabbit embryos activated with inositol 1,4,5-trisphosphate. Biol Reprod 1999; 60: 821-827.

13. Yang X, Presicce GA, Moraghan L, Jiang SE, Foote RH. Synergistic effect of ethanol and cycloheximide on activation of freshly matured bovine oocytes. Theriogenology 1994; 41: 395-403.

14. Ma SF, Liu XY, Miao DQ, Han ZB, Zhang X, Miao YL, et al. Parthenogenetic activation of mouse oocytes by strontium chloride: a search for the best conditions. Theriogenology 2005; 64: 1142-1157.

15. Yi YJ, Park CS. Parthenogenetic development of porcine oocytes treated by ethanol, cycloheximide, cytochalasin B and 6-dimethylaminopurine. Anim Reprod Sci 2005; 86: 297-304.

16. Leal CL, Liu L. Differential effects of kinase inhibitor and electrical stimulus on activation and histone $\mathrm{H} 1$ kinase activity in pig oocytes. Anim Reprod Sci 1998; 52: 51-61.

17. Fukui $Y$, Sawai K, Furudate M, Sato N, Iwazumi $Y$, Ohsaki $\mathrm{K}$. Parthenogenetic development of bovine oocytes treated with ethanol and cytochalasin B after in vitro maturation. Mol Reprod Dev 1992; 33: 357-362.

18. Collas $\mathrm{P}, \mathrm{Robl} \mathrm{JM}$. Factors affecting the efficiency of nuclear transplantation in the rabbit embryo. Biol Reprod 1990; 43: 877-884.

19. Yang $\mathrm{X}$, Jiang $\mathrm{S}$, Kovacs A, Foote RH. Nuclear totipotency of cultured rabbit morulae to support full-term development following nuclear transfer. Biol Reprod 1992; 47: 636-643.

20. Tomashov-Matar R, Tchetchik D, Eldar A, Kaplan-Kraicer $\mathrm{R}$, Oron Y, Shalgi R. Strontium-induced rat egg activation. Reproduction 2005; 130: 467-474.

21. Jellerette $T$, He CL, Wu H, Parys JB, Fissore RA. Downregulation of the inositol 1,4,5-trisphosphate receptor in mouse eggs following fertilization or parthenogenetic activation. Dev Biol 2000; 223: 238-250.

22. McDougall A, Sardet $C$. Function and characteristics of repetitive calcium waves associated with meiosis. Curr Biol 1995; 5: 318-328.

23. Vincent $\mathrm{C}$, Cheek TR, Johnson $\mathrm{MH}$. Cell cycle progression of parthenogenetically activated mouse oocytes to interphase is dependent on the level of internal calcium. $J$ Cell Sci 1992; 103 (Part 2): 389-396.

24. Ozil JP, Swann K. Stimulation of repetitive calcium transients in mouse eggs. J Physiol 1995; 483 (Part 2): 331346.

25. Chatot CL, Lewis JL, Torres I, Ziomek CA. Development of 1-cell embryos from different strains of mice in CZB medium. Biol Reprod 1990; 42: 432-440.

26. Ben-Yosef D, Oron $\mathrm{Y}$, Shalgi R. Intracellular $\mathrm{pH}$ of rat eggs is not affected by fertilization and the resulting calcium oscillations. Biol Reprod 1996; 55: 461-468.

27. Pittenger MF, Mackay AM, Beck SC, Jaiswal RK, Douglas $\mathrm{R}$, Mosca JD, et al. Multilineage potential of adult human mesenchymal stem cells. Science 1999; 284: 143-147.

28. Krivokharchenko A, Popova E, Zaitseva I, Vil'ianovich L, Ganten D, Bader M. Development of parthenogenetic rat embryos. Biol Reprod 2003; 68: 829-836.

29. Hyslop LA, Nixon VL, Levasseur M, Chapman F, Chiba K, 
McDougall A, et al. $\mathrm{Ca}\left({ }^{2+}\right)$-promoted cyclin $\mathrm{B} 1$ degradation in mouse oocytes requires the establishment of a metaphase arrest. Dev Biol 2004; 269: 206-219.

30. Jones KT. Turning it on and off: M-phase promoting factor during meiotic maturation and fertilization. Mol Hum Reprod 2004; 10: 1-5.

31. Nixon VL, McDougall A, Jones KT. $\mathrm{Ca}^{2+}$ oscillations and the cell cycle at fertilisation of mammalian and ascidian eggs. Biol Cell 2000; 92: 187-196.

32. Carroll J. The initiation and regulation of $\mathrm{Ca}^{2+}$ signalling at fertilization in mammals. Semin Cell Dev Biol 2001; 12: 3743.

33. Webb RJ, Bains H, Cruttwell C, Carroll J. Gap-junctional communication in mouse cumulus-oocyte complexes: implications for the mechanism of meiotic maturation. Reproduction 2002; 123: 41-52.

34. Homa ST, Carroll J, Swann K. The role of calcium in mammalian oocyte maturation and egg activation. Hum Reprod 1993; 8: 1274-1281.
35. Wakayama T, Perry AC, Zuccotti M, Johnson KR, Yanagimachi R. Full-term development of mice from enucleated oocytes injected with cumulus cell nuclei. Nature 1998; 394: 369-374.

36. Ogura A, Inoue K, Takano K, Wakayama T, Yanagimachi R. Birth of mice after nuclear transfer by electrofusion using tail tip cells. Mol Reprod Dev 2000; 57: 55-59.

37. Liu L, Ju JC, Yang X. Differential inactivation of maturationpromoting factor and mitogen-activated protein kinase following parthenogenetic activation of bovine oocytes. Biol Reprod 1998; 59: 537-545.

38. Liu L, Trimarchi JR, Keefe DL. Haploidy but not parthenogenetic activation leads to increased incidence of apoptosis in mouse embryos. Biol Reprod 2002; 66: 204-210.

39. Latham KE, Akutsu H, Patel B, Yanagimachi R. Comparison of gene expression during preimplantation development between diploid and haploid mouse embryos. Biol Reprod 2002; 67: 386-392. 